\title{
1. Real investigative journalism in a virtual world
}

COMMINANARY

Dumbing down media content undermines democracy. News media need to unleash the full power of investigative journalism. Every investigative story that goes in-depth and behind the scenes will actually strengthen democracy and the free press. The hope was that information technology would level the playing field and bridge the digital divide existing globally and within our countries. But, this commentary argues, technology alone is never the answer. Information technology is not value-free either and is not, by itself, going to provide answers to deep-seated structural problems of governance, social justice and equity.

Keywords: democracy, information technology, investigative journalism, photojournalism, war correspondence, social justice

KUNDA DIXIT,

Editor-in-chief, Nepali Times

OVERING conflicts in various parts of the Asia-Pacific region during the 1990 s, many of us were 'parachutists'. We dropped in, filed our stories and flew out. We were 'war correspondents'. We behaved like the soldiers we covered, thronged to bars and talked in military jargon. We rushed to the sites of the latest battle, or walked into the bush to interview insurgent leaders, staying only long enough to get a couple of good quotes. We memorised the names of the hardware of war, we were infatuated with the killing machines. We chronicled the carnage.

In 1996, when I returned to Nepal after covering conflicts in Sri Lanka, the Philippines and elsewhere, the last thing I had expected was to have to report on a conflict in my own country. 


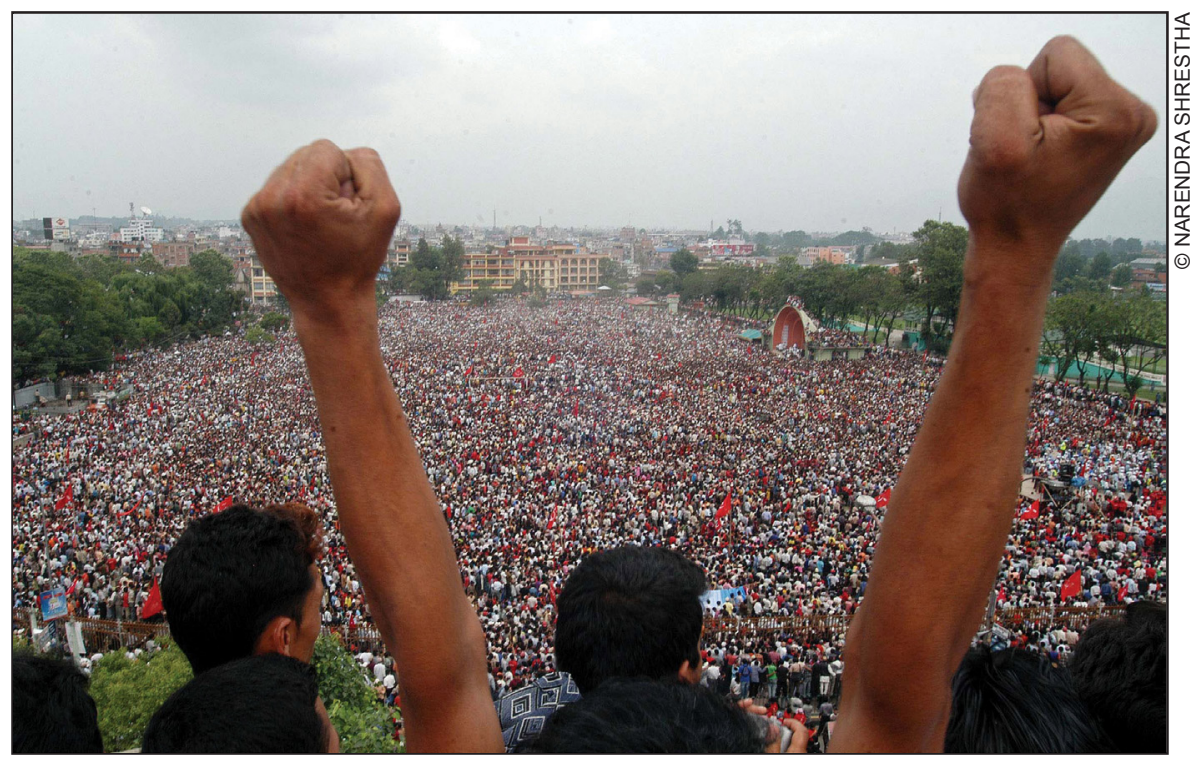

Figure 1: A supporter cheers from the roof of Bir Hospital in Kathmandu watching 200,000-strong crowd at a Maoist victory rally in June 2006.

The Maoist rebels had just launched their armed struggle against the Nepali monarchy.

Suddenly, this was not someone else's war anymore-it was happening in my own country, in my own society. My own people were killing each other.

Journalism schools teach us to be observers, not to get too involved, to keep a distance. But, back home, you couldn't be just a spectator anymore. We had to examine our own role as journalists. Did our reporting perpetuate conflict or was it going to help restore peace? We had to look beyond the battles, to how the war was affecting ordinary people. We had to investigate its human cost, expose those who benefited from conflict.

We had to be involved in finding a solution to the conflict.

Such attachment is not permitted under prevailing journalism rules. They teach us never to get too close, never get too involved in a story. But our problem in Nepal was that the media was not involved enough. For ten years of the conflict, it was satisfied with sitting in the sidelines counting the body bags. Stories of civilian victims are too soft for a hard news-led lineup. There is no space for long, in-depth human interest photo features. To go deeper into the story, many of us had to turn to other formats. Some of my colleagues 
shifted to documentary films focusing on children, women, teachers, farmers caught in the crossfire. The video format allowed them to go really in-depth, and be investigative.

\section{The truth through pictures}

One of my friends even wrote a novel about the war. He actually turned to fiction to get closer to the truth because he said journalism was too restrictive. I myself decided to use the medium of still photography to recall what the war did to our country, society and people. Pictures don't just tell a thousand words, they show us what happens. Pictures remind us to remember, so the violence and brutality is not repeated.

Photojournalists by definition have to be there, they can't do phone interviews from the safety of the capital. Journalists need to be witnesses not just to what combatants go through, but of what the violence does to those who want no part in it.

In all modern wars, it is mostly the civilians who die, civilians are maimed, civilians disappear or are displaced. Our job is to jog the conscience of those in power, to make them feel so guilty, that they will do something for the victims of the war that they fought in the name of liberation.

Nepal's war has been over for nearly five years now, and the images form a part of the healing process so that journalism can help in reconciliation. The images of suffering are universal. The faces of bereavement, the pain and tears could be anywhere in the world.

It will probably not surprise you that there are people who argue against portraying the pain of war. Looking at war only from the standpoint of 'victimhood', they say, helps perpetuate the status quo and works against social reform. In fact, the word 'pacifist' has a slightly derogatory edge to it these days. For warmongers, it seems, people who speak out for peace and nonviolence are enemies. How else do you explain the fact that country with the largest army in the world, one that has nuclear weapons and is poised to become the world's next superpower, is so scared of a monk who preaches peace and compassion?

Not surprisingly, throughout history, it is the leaders who talk of peace and love, those who try to stop the madness of war, who are assassinated. Media has a role in nurturing and protecting peace by exercising its freedom in the protection of democracy. 
INVESTIGATIVE JOURNALISM

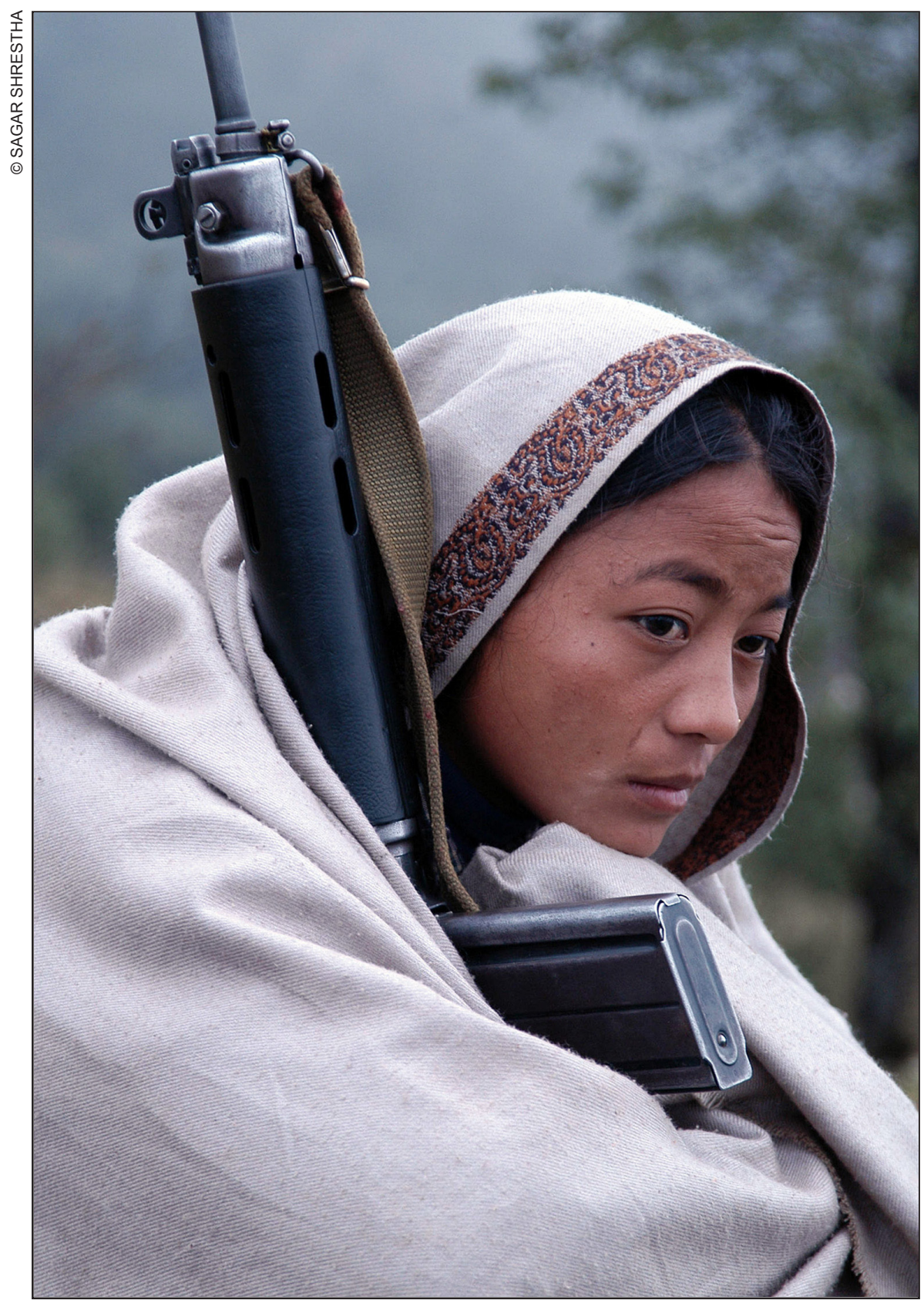

Figure 2: Twenty-year-old Juna Rai on sentry duty at a Maoist camp near Bhojpur, Nepal, in November 2005. 


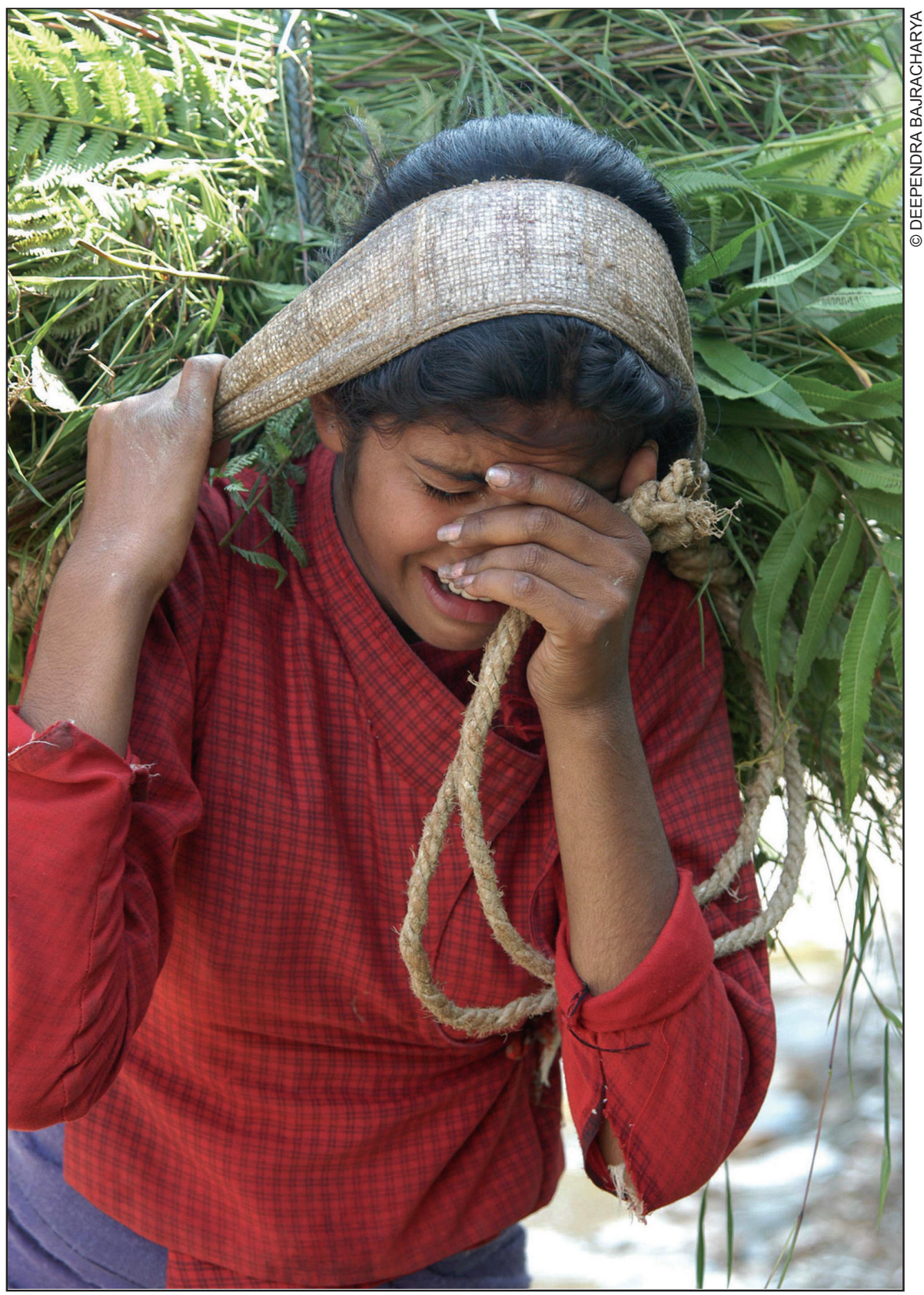

Figure 3: Sixteen-year-old Sumitra Adhikari carries fodder for the family livestock at Chhaimale, near Kathmandu, Nepal, in 2004. 
These days, journalists are embedded and war is reduced to being a video game. There are people who don't want the public to see the blood and dismembered bodies. By colluding with militaries that want to sanitise the public's perception of a war, by dehumanising it, wars can be waged on television almost as entertainment.

This was the enduring legacy of Vietnam, where images of a dirty war beamed to living rooms in America created a backlash, turned public opinion and ultimately led to that image of the airlifting of the last US personnel from the roof of the embassy in Saigon. Ever since, militaries around the world have learnt their lesson. Wars need to be fought in the realm of public opinion, which means showing the media only what you want the media to see. Great care is now taken to limit access and filter the images coming out. What armies fear the most these days is an outbreak of peace.

The media also misses out on the precursors to war, so that when violence does erupt we are surprised and shocked. We journalists are taught to be ambulance chasers, we arrive at the scene after the event. There is no room in the news slots of the international media for slowly emerging crises, the inequities and injustice that drive people to violence, or a country that is slowly sinking into the quagmire of ethno-separatist conflict.

And if that conflict involves a little known part of the world, it is even more unlikely to get our attention. The media spotlight is on Afghanistan, Iraq or the Koreas because the West is involved. But potential hotspots like West Papua and Madagascar fall between the cracks.

Intelligent, in-depth reporting is not easy, it needs reporters who have investigative skills and the tenacity dive deep. They need to know how to package it and be good at selling it to their bosses and then to the public at large. All journalism needs to be investigative; it is the only real journalism in a virtual world.

But more than the skills and craft, I think it is important to approach investigative journalism as a philosophy. This means aside from asking 'how to' investigate we also ask ourselves 'why' and 'what' to investigate. Why am I doing this particular story, what impact will it have, will it make things better, is it just for my own fame and glory? And the most important question: Why am I a journalist? What is it I want to achieve by being in this profession?

\section{When corruption is endemic}

In some countries, it may be important to investigate corruption, to even go 
undercover, or use hidden cameras to expose dishonest officials and elected leaders who lack accountability. But what do you do when corruption is endemic? In a society like that, using entrapment techniques to expose a cop taking a payoff will not be as relevant. It may be much more important to train reporters to show the light on the media's blind spots, train them to go to terrain which reporters are traditionally trained to ignore.

A lot of it has to do with the pace of news. The event-driven news format needs sudden disasters. Slowly unfolding trends like increasing poverty and climate change are much more difficult to cover. It's much harder to get gatekeepers of media interested in silent emergencies. Let's face it, for something to make it to Breaking News on CNN a lot of well-to-do people in a rich country have to die suddenly and spectacularly. And if they do the dying on camera, and we have visuals, it is even more newsworthy. But poor children and women dying silently, separately, of preventable causes doesn't make news. It never has. Thousands of cotton farmers commit suicides because of falling prices and indebtedness. But each suicide is covered as an event by the reporter in the crime beat, and not investigated as a trend.

I want to also touch upon the argument gaining fashionability among Asian countries that democracy and free press are luxuries we can't afford. It is as if only the rich deserve political rights and freedom. A distinction is made between individual freedom and the social, economic and cultural rights of people, the argument being that the right to vote in a democracy doesn't make any sense unless the voter first has enough to eat.

At first glance this does appear to be true. Some of the poorest countries in our region are the ones that can be classified as 'democratic', and the economies that are growing fastest are ones where pluralism is not allowed. In South Asia politicians look longingly at the East Asian model, arguing that it would help spur economic growth.

The argument has many flaws. You don't need authoritarianism for growth. In Asia, there are examples of military regimes and Stalinist dictatorships where citizens don't have enough to eat, just as there are examples of countries that have prospered because they were democracies. In my own country, Nepal, we have tried partyless dictatorship, absolute monarchy, royal-military regimes and they were all much worse than democracy. Dictators and despots tend to plunder their countries, setting back development by decades. And it is usually dictators and demagogues who take their countries to war. 
Democracy is messy and elected politicians tend to be crooks. But it is still the best among the bad political models we have. At least in a democracy, there are mechanisms in place to set things right, and the rules of the game don't allow violence to be used as a political tool. We should be trying to ensure that democracy works better, we should protect and strengthen democratic institutions and so that it helps deliver development. The misdeeds of some politicians should not tarnish the system. And we don't just want democracy for the sake of democracy; it is the competition of political ideas and the leadership skills of candidates that must lead to an improvement of people's lives.

\section{Two sides of the same coin}

An essential part of this mechanism is journalism. Independent media and free politics go hand in hand. Press freedom and democracy are two sides of the same coin. Curtailing press freedom hurts democracy and vice-versa. There are enormous challenges for the media to overcome this role. Some are old, some are new. In some countries in the region, even democratic ones, professional hazards for journalists have got so serious that reporters risk their lives every day to investigate stories like illegal logging.

The rapid advances in information technology and its convergence is reflected in the concentration of ownership and control of media. An overcommercialised media in many of our countries has distorted and eroded the media's public service role. The lesson is that press freedom doesn't come with any warranty. It has to be defended by is maximum application. The threats to media freedom don't just come from tyrants and dictators; they come from owners who see it as just another business, from under motivated journalists, from publishers who turn their products into trivial tabloids because that is where the money is.

Dumbing down content undermines democracy. This is why we need to unleash the full power of investigative journalism. Every investigative story that goes in-depth and behind the scenes will actually strengthen democracy and the free press. The hope was that information technology would level the playing field and bridge the digital divide existing globally and within our countries. But as we know by now, technology alone is never the answer. Information technology is not value-free either and is not, by itself, going to provide answers to deep-seated structural problems of governance, social justice and equity. 
Rulers, even democratically elected leaders, tend to look at the media as a threat. In fact, the trend across Asia is that elected leaders try to use the privileges of office to stay on in power and crack down on a critical media. Media has to be vigilant in countering elected despots who use their mandate to destroy the very institutions that allowed them to be voted to power in the first place.

Finally, we have to ask ourselves what it is all for. Why are we, in the media business? The challenge, I think, is for the media to cover the democratic process so that it improves service delivery, development and economic growth. Let's work on a paradigm shift in the way we in the media approach stories. We should strive to cover deprivation and the causes of social injustice, not just its effect. It means each of us having a conscience and using it: by striving to be fair in an unfair world.

Kunda Dixit is a Nepali journalist who worked as news reporter for the BBC in New York, and then as Asia-Pacific director of Inter Press Service and reported in the Pacific. He returned to Nepal in 1996 to set up Panos South Asia, where he was director from 1997 to 2000. He is currently editor-in-chief of the Nepali Times and publisher of the Himal Media Group. He is author of Dateline.Earth: Journalism.as.if.the.planet.mattered (recently republished) and editor of the A People War trilogy collection of photojournalism. He was also the lead keynote speaker of the Media, Investigative Journalism and Technology (MIJT10) conference at Aut University on 4-5 December 2010. kunda@nepalitimes.com 